\title{
DETERMINATION OF THE AVERAGE ABSORBED ENERGY OF ELECTRONS BEAM IN OBJECTS AT RADIATION PROCESSING
}

\author{
V.T. Lazurik', V.M. Lazurik', G.Ph. Popov ${ }^{1}, Z_{\text {Z. Zimek }}^{2}$ \\ ${ }^{1}$ V.N. Karasin Kharkiv National University, Kharkiv, Ukraine; \\ ${ }^{2}$ Institute of Nuclear Chemistry and Technology, Warsaw, Poland
}

\begin{abstract}
A new conservative computational procedure is proposed for calculating the average absorbed energy of electron radiation in objects undergoing radiation processing. Semi-empirical relationships were obtained and software for dosimetry of electron radiation was developed. A comparison was made of the results obtained using the proposed method with the results of known and traditional methods of electron radiation dosimetry as well as with the results of measurements performed at the sterilization center of the Institute of Nuclear Chemistry and Technology, Warsaw, Poland was carried out.
\end{abstract}

PACS: 29.27.-a; 07.81.+a

\section{INTRODUCTION}

High energy electron accelerators powered by magnetron type of RF source are frequently used in radiation sterilization process [1]. Such device implementation in accelerator may leads to relatively high instability of electron energy and electron energy spread [2, 3]. Day-to-day reproducibility of electron energy and energy spread may be deteriorated by several different reasons like bad quality exploitation, influence outside temperature on accelerator parameters, weak or bad quality components responsible for electron accelerating process. It should be also noticed that electron beam energy spread is not currently measured in radiation facilities.

The variation of electron energy spread in sterilization facility was investigated with application of computational method for determination of e-beam energy on the base of two-parametric fitting depth dose distribution curve $[4,5]$. Method can effectively consider electron energy spread value influence on experimental data obtained by the use of aluminum wedge with a continuous polymer strip of dosimetry film [6]. The total effect corresponds to energy losses in accelerator output window, distance between window and irradiated material surface and initial energy spread of electron beam. The e-beam energy losses due to window and air presence are constant for certain electron energy level and specific geometry of irradiation zone. Those energy losses can be estimated on the base of existing literature data [7]. Therefore initial e-beam energy spread and its variation can be evaluated by processing the depth dose distribution data connected to $R_{p}$ (practical range) measurements by two-parametric fitting method. The practical range $R_{p}$ is defined as depth where extrapolated straight line plotted through the steepest section of electron depth dose curve meets depth. It should be noticed that influence of electron energy spread on conditions of radiation processing were investigated experimentally long time ago [2]. The following conclusions were formulated: information about the energy spectrum of electron beam is necessary for proper general description but it is less essential for the given radiation installation. The presence of energy spectrum in electron beam can change intensity of the scanned electron beam, what should be considered by suitable arrangement of the beam scanning device.
In this work, applied methods of investigation were as follow:

- Computational experiments with e-beams of different spectra; selection of mathematical models of the ebeam spectra and determination sets of spectrum for performing the numerical investigations;

- Modeling the depth dose distribution of electron radiation in an aluminum target with Monte-Carlo method based on detailed physical model covered by RT-Office software [8];

- Processing of computer experiments results with standard methods, that is used in the electron radiation dosimetry with techniques of dosimetry wedge;

- Procedures described in "Radiation dosimetry: electron beams with energies between 1 and $50 \mathrm{MeV}$ " [7, 9];

- Comparison results of the computer experiments to identify the characteristics dose distributions dependency from the model parameters of the e-beam spectra.

\section{MODELS OF THE ENERGY SPREAD OF ELECTRONS USED IN THE NUMERICAL INVESTIGATIONS}

The depth dose distribution initiated by e-beam with energy spread in aluminum was investigated. Dose distribution can be described by formula:

$$
D_{M}(x)=\int_{E \min }^{E \max } S(E) \cdot D_{M}(x, E) d E,
$$

where $S(E)$ - electron beam energy spectrum; $D_{M}(x)$ - depth dose distribution of electrons radiation in material $\mathrm{M} ; D_{M}(x, E)$ - depth dose distribution in material $\mathrm{M}$ irradiated by monoenergetic electron beam with energy E.

The numerical studies were performed for which uniform and triangular probabilities of energy distribution were used to describe the spectrum of electrons. The spectrum of the model with uniform distribution of the electron energy was defined by two parameters: $E_{\text {min }}$ (minimum) and $E_{\max }$ (maximum) value of the energy of electrons within the beam. The spectrum in the model of the triangular distribution of electron energies was defined by three parameters: $E_{\min }$ and $E_{\max }$ as before and $E_{p}$ the most probable value of the electrons energy in the beam. The most probably energy $E_{p}$ is defined as an 
energy at which electron energy spectrum curve has the maximum. Physical quantities with the stochastic nature, such as the electrons spectrum or the angular distribution of the electrons (the terms of probability theory) were used for description. For example, when the electron energy in the beam is a random variable, the energy spread of the electrons (the term in physics electron spectrum) describes the density function of the random variable probability. Herewith, the value $E_{p}$ is called the mode of the probability density of a random variable.

The notation $\mathrm{S}\left(E_{\min }, E_{\max }\right)$ was introduced for description the model spectra of uniform electron energy distribution. The notation $\mathrm{S}\left(E_{\min }, E_{p}, E_{\max }\right)$ was applied for the triple parameters, describing the triangle distribution of electron energy spectrum. According to above notations, expression $\mathrm{S}(10,10)$ or $\mathrm{S}(10,10,10)$ describes a mono-energetic electron beam with energy $10 \mathrm{MeV}$ energy in the model of uniform or triangular electron energy distribution in the beam.

As example, Fig. 1 shows electron spectra for uniform and triangular models of the electron energy distribution in the beam. The dashed curve shows the spectrum of electrons in a symmetrical pattern of the triangular electron energy distribution. It can be noticed examples of entries symmetric $S(6,8,10)$ and asymmetric $\mathrm{S}(6,10,10)$ spectra of electrons in the beam.

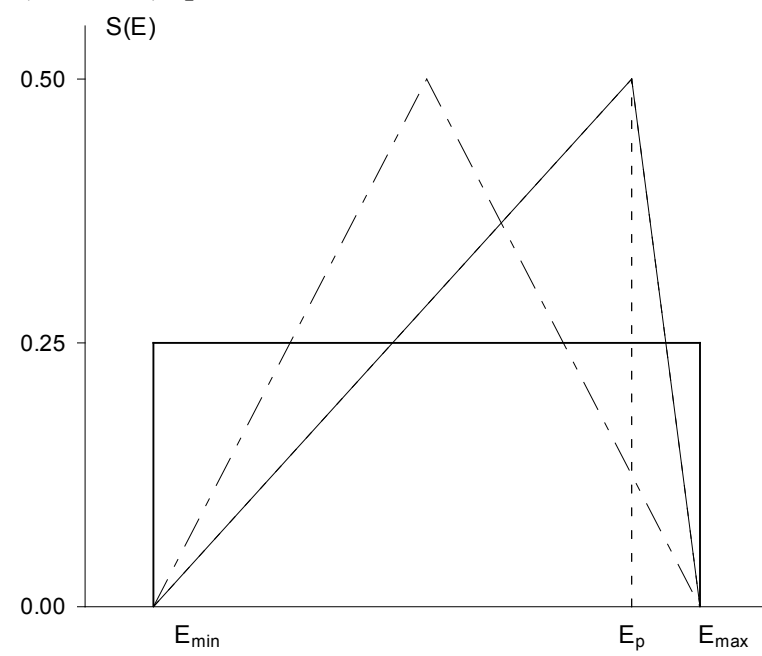

Fig. 1. Models of the electron beam spectrum: uniform and triangular distributions of the electron energy

The ratios for the mean value $M(\xi)$ and variance $D^{2}(\xi)$ of the random variable $\xi$ having a uniform probability distribution:

$$
\begin{gathered}
M(\xi)=\left(E_{\min }+E_{\max }\right) / 2, \\
D^{2}(\xi)=\left(E_{\max }-E_{\min }\right)^{2} / 12 .
\end{gathered}
$$

For a triangular probability distribution:

$$
M(\xi)=\left(E_{\min }+E_{p}+E_{\max }\right) / 3
$$

$D^{2}(\xi)=\left(\left(E_{\min }^{2}+E_{p}^{2}+E_{\text {max }}^{2}\right)-\left(E_{\min } \cdot E_{p}+E_{p} \cdot E_{\text {max }}+E_{\text {min }} \cdot E_{\text {max }}\right)\right) / 18$,

$$
\sigma=\sqrt{D^{2}(\xi)}
$$

\section{COMPUTER EXPERIMENTS}

The first series of computer experiments were performed for studying possibility of calculating the most probable energy of electrons beam $E_{p}$ with use the value of practical range $R_{p}$ of electrons [7,9]. The value of practical range $R_{p}$ of the electrons was determined by measuring the depth dose distribution results in a standard dosimetry device (aluminum dosimetry wedge). A set of model spectra of electrons has been selected with different energy spread for performing the numerical experiments with fixed (the same) the most probable energy of the electrons in the beam $E_{p}=10 \mathrm{MeV}$. Fig. 2 presents examples of the spectra in this set.

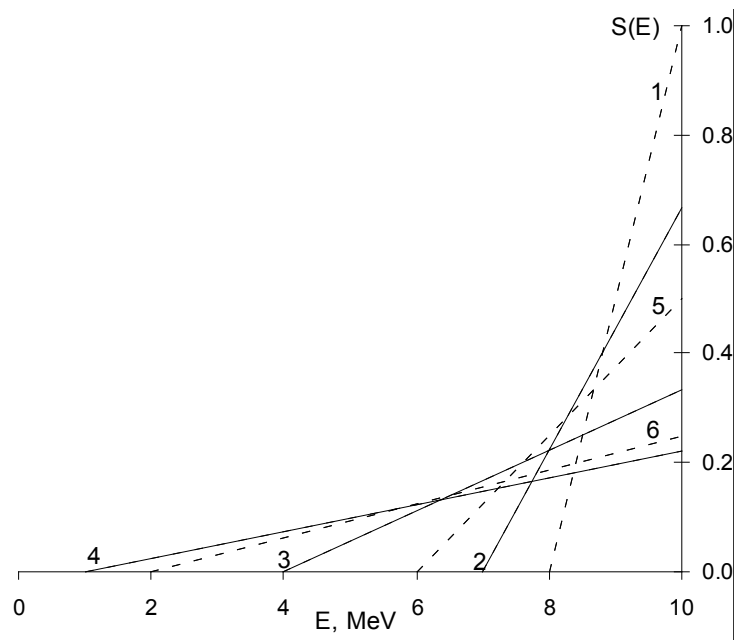

Fig. 2. Electrons spectra in the model of triangular distribution the electrons energy with different energy spread, but with fixed the most probably energy of the electrons in the beam $\left(E_{p}=10 \mathrm{MeV}\right)$

The second series of computer experiments it was suggested, that most probably energy of electrons $E_{p}=$ $10 \mathrm{MeV}$ and average energy $E_{A v}=9 \mathrm{MeV}$. The values of energy spread of the source electrons were determined by choice of the model parameters of electron spectrum, and were determined by the value of $\sigma$-rootmean-square deviation of the source electron energy.

Calculations of depth dose distributions of electron radiation in an aluminum target were performed according to Monte Carlo method according to detailed physical model applied at RT-Office software [8]. Calculations were performed with mono-energetic electrons beam (energy $10 \mathrm{MeV}$ ) and electron beams with different energy spread, which are shown in Fig. 2 and Table 1.

Table 1

Parameters of the electron spectrum model $S(E)$ in the form of a triangular probability distribution

\begin{tabular}{|c|c|c|c|c|c|}
\hline Spectrum & $E_{\min }$ & $E_{p}$ & $E_{\max }$ & $E_{A v}$ & $\sigma$ \\
\hline $\mathrm{S}_{\min }$ & 7 & 10 & 10 & 9 & 0.71 \\
\hline $\mathrm{S}_{1}$ & 6.2 & 10 & 10.8 & 9 & 1.00 \\
\hline $\mathrm{S}_{2}$ & 5.1 & 10 & 11.9 & 9 & 1.43 \\
\hline $\mathrm{S}_{3}$ & 4.3 & 10 & 12.7 & 9 & 1.75 \\
\hline $\mathrm{S}_{4}$ & 3.7 & 10 & 13.3 & 9 & 2.00 \\
\hline $\mathrm{S}_{5}$ & 3.1 & 10 & 13.9 & 9 & 2.23 \\
\hline
\end{tabular}




\section{RESULTS CALCULATION AND DISCUSSION}

Procedures for determination the practical range $R_{p}$ of electrons and adequately the depth of half dose reduction $R_{50}$ for normalized depth dose distributions, were performed (Table 2). The values of most probably energy $E_{p}^{*}$ and average electron beam energy $E_{A v}^{*}$ were calculated according to the formulas:

$$
\begin{gathered}
E_{p}^{*}=5.09 \cdot R_{p}+0.2, \\
E_{A v}^{*}=6.2 \cdot R_{50} .
\end{gathered}
$$

Practical range $R_{p}$ of electrons and depth of the half-dose reduction $R_{50}$ in aluminum irradiated by electron beams with different spectra

\begin{tabular}{|l|l|l|l|l|l|}
\hline $\begin{array}{c}\text { Parame- } \\
\text { ters }\end{array}$ & $M(E)$ & $R_{p}$ & $R_{50}$ & $E_{p}^{*}$ & $E_{A v}^{*}$ \\
\hline S0 & 10.00 & 2.01 & 1.61 & 10.46 & 9.98 \\
\hline S1 & 9.33 & 1.89 & 1.50 & 9.82 & 9.3 \\
\hline S2 & 9.00 & 1.83 & 1.44 & 9.49 & 8.93 \\
\hline S3 & 8.00 & 1.73 & 1.28 & 9.02 & 7.94 \\
\hline S4 & 7.00 & 1.68 & 1.18 & 8.77 & 7.32 \\
\hline S5 & 8.67 & 1.78 & 1.38 & 9.28 & 8.56 \\
\hline S6 & 7.33 & 1.69 & 1.22 & 8.78 & 7.56 \\
\hline
\end{tabular}

Comparison of the mean energy of electrons $M(E)$ with those obtained on the basis of the standard depth dose distribution processing procedure, reviles that values of the average energy of electrons in the beam $E_{A v}^{*}$ showed their correlation, even for large values of the relative standard deviations energy of electrons.

The second series of computer experiments were processed by method based on two parametric model of the electron beam [4]. Results of treatment of dose distributions in aluminum by the method of one-parametic (values $E_{1}$ ), and on the basis of two parametric model of the electron beam (parameters $E_{0}, X_{0}$ ) are shown in Table 3 .

Table 3

The results of calculation

\begin{tabular}{|c|c|c|c|c|c|}
\hline $\begin{array}{c}\text { Spec- } \\
\text { trum }\end{array}$ & $\begin{array}{c}\sigma / E_{A v} \\
{[\%]}\end{array}$ & $\begin{array}{c}D^{2}, \\
{[\mathrm{MeV}]}\end{array}$ & $\begin{array}{c}E_{1}, \\
{[\mathrm{MeV}]}\end{array}$ & $\begin{array}{c}E_{0}, \\
{[\mathrm{MeV}]}\end{array}$ & $\begin{array}{c}X_{0}, \\
{[\mathrm{~cm}]}\end{array}$ \\
\hline $\mathrm{S}_{\min }$ & 7.86 & 0.5 & 9.14 & 9.28 & 0.023 \\
\hline $\mathrm{S}_{1}$ & 11.11 & 1.0 & 9.15 & 9.58 & 0.069 \\
\hline $\mathrm{S}_{2}$ & 15.71 & 2.0 & 9.21 & 10.32 & 0.180 \\
\hline $\mathrm{S}_{3}$ & 19.25 & 3.0 & 9.26 & 11.10 & 0.300 \\
\hline $\mathrm{S}_{4}$ & 22.22 & 4.0 & 9.36 & 11.64 & 0.376 \\
\hline $\mathrm{S}_{5}$ & 24.85 & 5.0 & 9.44 & 12.39 & 0.488 \\
\hline
\end{tabular}

As can be seen from Table 3, with increase in the energy spread of electrons source $\sigma$ (dispersion $D^{2}$ ), it is increases the difference between energy $E_{1}$, obtained using a one-parameter fitting and energy $E_{0}$, obtained by two parametric fitting of semi-empirical model to results of modeling the depth distributions of electron radiation dose in an aluminum target. The comparison of approximating expressions is shown in Fig. 3.

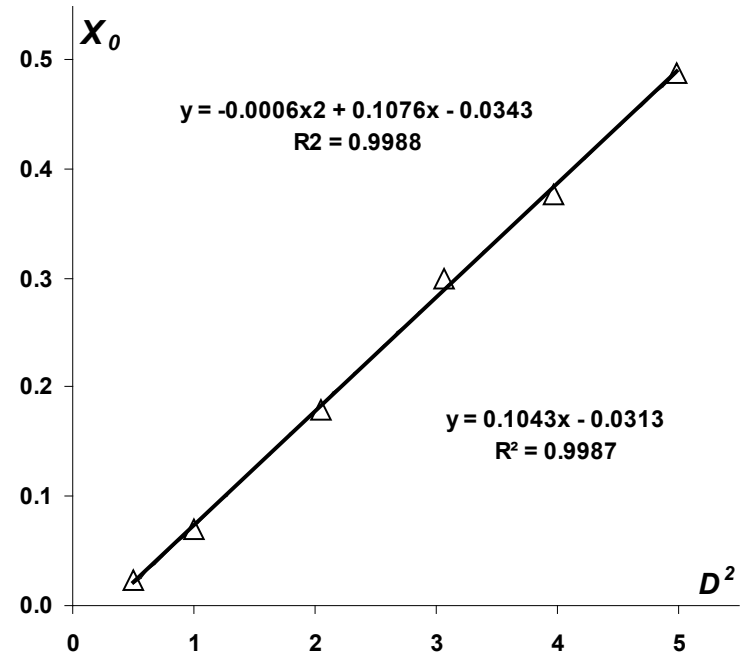

Fig. 3. Dependence of the parameters $X_{0}$ on value of the dispersion $D^{2}$

It is observed a linear dependence of the displacement parameter $X_{0}$ of dose distribution on value of electron energy dispersion $D^{2}$ for model spectra of electrons source.

\section{CONCLUSIONS}

In the presence of an energy spread of electrons: the value $R_{50}$ is suitable for determining average electron energy $E_{A v}$; the value $R_{p}$ should not be used to determine the most probable electron energy of the source $E_{p}$. The method based on two parametric electron beam models is in good agreement with standard methods of processing dosimeter measurements in a wide range of the energy spread of source electrons. It is possible to determine the value of electron energy dispersion $D^{2}$ from value of displacement parameter $X_{0}$ of dose distribution calculated by method on basis of two parametric model of electron beam [4].

\section{REFERENCES}

1. Z. Zimek, L. Waliś, A.G. Chmielewski. Industrial facility for radiation sterilization of medical devices // Radiat. Phys. Chem. 1993, v. 42, p. 571-572.

2. Z.P. Zagórski. Dependence of dept-dose distribution on the energy spectrum of 5 to $13 \mathrm{MeV}$ electron beams // Radiat. Phys. Chem. 1983, v. 22, № 3-5, p. 409-418.

3. V.T. Lazurik, V.M. Lazurik, G. Popov, Z. Zimek. Determination of electron beam parameters on radiation-technological facility for simulation of radiation processing // East European Journal of Physics. 2014, v. 1, № 3, p. 74-78.

4. V.M. Lazurik, V.T. Lazurik, G. Popov, Z. Zimek. Two-parametric model of electron beam in computational dosimetry for radiation processing // Radiat. Phys. Chem. 2016, v. 124, p. 230-234. 
5. V.T. Lazurik, V.M. Lazurik, G.Ph. Popov, Z. Zimek. Method of Dosimetry Based on a Two-Parametric Model of Electrons Beam for Radiation Processing // Problems of Atomic Science and Technology. 2017, № 6, p. 137-141.

6. L. Pages, E. Bertel, H. Joffre, L. Sklavenitis. Pertesd'energie, parcours et rendement de freinage pour less electrons de $10 \mathrm{keV}$ to $100 \mathrm{MeV}$ dans les elements simples et quelques composes chimiques // Rapport CEA-R-3942, 1970.

7. Radiation dosimetry: electron beams with energies between 1 and $50 \mathrm{MeV}$, ICRU REP. 1984, 35, $160 \mathrm{p}$.
8. V.M. Lazurik, V.T. Lazurik, G. Popov, Yu. Rogov, Z. Zimek. Book Information System and Software for Quality Control of Radiation Processing // IAEA Collaborating Center for Radiation Processing and Industrial Dosimetry. Warsaw, Poland. 2011, 220 p.

9. ISO/ASTM Standard 51649: Practice for dosimetry in an e-beam facility for radiation processing at energies between $300 \mathrm{keV}$ and $25 \mathrm{MeV} / /$ Annual Book of ASTM Standards. 2005, v. 12.02.

Article received 18.10.2019

\section{ОПРЕДЕЛЕНИЕ СРЕДНЕЙ ПОГЛОЩЕННОЙ ЭНЕРГИИ ПУЧКА ЭЛЕКТРОНОВ В ОБЪЕКТАХ ПРИ РАДИАЦИОННОЙ ОБРАБОТКЕ}

\section{В.Т. Лазурик, В.М. Лазурик, Г.Ф. Попов, З. Зимек}

Предложена новая консервативная вычислительная процедура расчета средней поглощенной энергии излучения электронов в объектах, проходящих радиационную обработку. Получены полуэмпирические соотношения и создано программное обеспечение для дозиметрии электронного облучения. Проведены сравнения результатов, полученных с использованием предложенного метода, с результатами известных и традиционных методов дозиметрии электронного излучения, а также с результатами измерений, выполненных в стерилизационном центре Института ядерной химии и технологий, Варшава, Польша.

\section{ВИЗНАЧЕННЯ СЕРЕДНЬОЇ ПОГЛИНЕНОЇ ЕНЕРГІЇ ПУЧКА ЕЛЕКТРОНІВ В ОБ'ЄКТАХ ПРИ РАДІАЦІЙНІЙ ОБРОБЦІ}

\section{В.Т. Лазурік, В.М. Лазурік, Г.Ф. Попов, З. Зімек}

Запропоновано нову консервативну обчислювальну процедуру розрахунку середньої поглиненої енергії випромінювання електронів в об'єктах, які проходять радіаційну обробку. Отримано напівемпіричні співвідношення і створено програмне забезпечення для дозиметрії електронного випромінювання. Проведено порівняння результатів, отриманих з використанням запропонованого методу, з результатами відомих і традиційних методів дозиметрії електронного випромінювання, а також з результатами вимірювань, виконаних у стерилізаційному центрі Інституту ядерної хімії і технологій, Варшава, Польща. 